\title{
Penyuluhan Pencegahan Penularan Covid-19 Melalui Edukasi Social Distancing pada Anak Sekolah Dasar di Dusun Nyelak
}

\author{
M Deni siregar ${ }^{*} 1$, Dukha Yunitasari ${ }^{1}$, I Dewa Putu Partha ${ }^{1}$ \\ ${ }^{1}$ Universitas Hamzanwadi, Lombok, Indonesia
}

\section{Article Info \\ Article history: \\ Received Oct $19^{\text {th }} 2020$ \\ Revised Oct $27^{\text {th }} 2020$ \\ Accepted Nov $12^{\text {th }} 2020$ \\ Published Nov $26^{\text {th }} 2020$}

\section{Keyword:}

Social Distancing

Education

Covid-19 Prevention

\section{Corresponding Author:}

\begin{abstract}
During this pandemic, the government appealed to social distancing as an effort to prevent the transmission of Covid-19. However, children actually do not understand what is happening and this understanding of social distancing is not fully understood by children because during childhood it is a play phase so that children activities and gather with their friends this will pose a risk of virus transmission. greater than. Therefore, during the Covid-19 pandemic, proper education is needed regarding the prevention of transmission of the virus to children. Providing children with an understanding of Covid-19 is very necessary so that children can prevent the transmission of the virus. Providing education to children about the corona virus or Covid-19 requires creativity and the delivery of information that is easily understood by children. Based on this, counseling activities on the prevention of covid-19 transmission were carried out through social distancing education for elementary school children in Nyelak Hamlet. This PKM aims to provide education and understanding to children and parents so that they can reduce gathering activities outside the home and avoid crowds while playing to prevent transmission of the virus. The content of this counseling is an understanding of the importance of effective social distance in preventing corona transmission, the reason for prohibiting social interaction with friends during the Covid-19 pandemic. With the implementation of this activity, it can provide understanding to children and parents so that they can avoid the transmission of Covid-19.
\end{abstract}

(C) 2020 The Authors. Published by IICET.

This is an open access article under the CC BY-NC-SA license

(https://creativecommons.org/licenses/by-nc-sa/4.0

M Deni siregar,

”' muhammaddenisiregar@gmail.com

\section{Pendahuluan}

Dunia dilanda musibah besar yang mengorbankan banyak sektor penting, kondisi yang melanda dunia pada bulan Februari hingga Mei 2020 sangat membuat masyarakat dunia menjadi resah dan panik, namun itu hanya di rasakan oleh para orang tua yang sangat menghawatirkan diri dan anak-anak mereka yang kini masih sering berkeliaran mencari teman bermain seperti biasa yang dilakukan anak-anak. Kita ketahui Coronavirus ( $\mathrm{CoV}$ ) adalah keluarga besar virus yang menyebabkan penyakit mulai dari gejala ringan sampai berat (Rothan \& Byrareddy, 2020; Zheng, 2020). Ada setidaknya dua jenis coronavirus yang diketahuimenyebabkan penyakit yang dapat menimbulkan gejala berat seperti Middle East Respiratory Syndrome (MERS) dan Severe Acute Respiratory Syndrome (SARS). Coronavirus Disease (COVID-19) adalah virus jenis baru yang belum pernah diidentifikasi sebelumnya pada manusia. Virus corona adalah zoonosis 
(ditularkan antara hewan dan manusia). Penelitian menyebutkan bahwa SARS ditransmisikan dari kucing luwak (civet cats) ke manusia danMERS dari unta ke manusia. Beberapa coronavirus yang dikenal beredar pada hewan namunbelum terbukti menginfeksi manusia (Chan, et al., 2020; Seah \& Agrawal, 2020). Manifestasi klinis biasanya muncul dalam 2 hari hingga 14 hari setelah paparan. Tanda dan gejala umum infeksi coronavirus antara lain gejala gangguan pernapasan akut seperti demam, batuk dan sesak napas. Pada kasus yang berat dapat menyebabkan pneumonia, sindrom pernapasan akut, gagal ginjal, dan bahkan kematian (Stankovska, Memedi, \& Dimitrovski, 2020).

Dengan kondisi seperti inilah pemerintah dan majlis ulama Indonesia serta seluruh ahli medis di negara kita mewajibkan menjaga kesehatan dan menggunakan masker serta mengikuti segala arahan dan aturan pemerintah untuk memutus mata rantai menularnya wabah Coronavirus Disease (COVID-19) (Hong, Wang, Chung, \& Chen, 2020). Anak-anak seusia sekolah dasar yang kini mendapatkan libur panjang darti pemerintah untuk mengalihkan proses pembelajaran daring di rumah saja tidak dihiraukan oleh sebagian anak-ana terutama yang tinggal di pedusunan, seperti apa yang terjadi di masyarakat Nyelak Kelurahan kelayu jorong, mereka bergaul dengan bebas dengan teman sebaya tanpa mengingat kondisi yang sebenarnya sangat berbahaya kalau tidak menjaga jarak bahkan tidak pernah memakai masker (Tezer \& Demirdağ , 2020). Jadi untuk menekan kebebasan anak dalam bergaul saya selaku pelaksana Pengabdian kepada Masyarakat (PKM) merasa terpanggil untuk mengadakan penyuluhan tentang pentingnya mengurangi interaksi sosial di tengan pandemi COVID-19 (Buana, 2020; Mallineni, et al., 2020; Sood, 2020).

Keputusan Pemerintah dan majlis ulama Indonesia (MUI) memaklumatkan nomor 14 tahun 2020 tentang penyelenggaran ibadah dalam situasi terjadi wabah covid-19: a) Setiap orang wajib melakukan ikhtiar menjaga kesehatan dan menjauhi setiap hal yang diyakini dapat menyebabkannya terpapar penyakit, karena hal itu merupakan bagian dari menjaga tujuan pokok beragama (al-Dharuriyat alKhams), b) Orang yang telah terpapar virus Corona, wajib menjaga dan mengisolasi diri agar tidak terjadi penularan kepada orang lain. Baginya shalat Jumat dapat diganti dengan shalat zuhur di tempat kediaman, karena shalat jumat merupakan ibadah wajib yang melibatkan banyak orang sehingga berpeluang terjadinya penularan virus secara massal. Baginya haram melakukan aktifitas ibadah sunnah yang membuka peluang terjadinya penularan, seperti jamaah shalat lima waktu/ rawatib, shalat Tarawih dan Ied di masjid atau tempat umum lainnya, serta menghadiri pengajian umum dan tabligh akbar, c) Orang yang sehat dan yang belum diketahui atau diyakini tidak terpapar COVID-19, harus memperhatikan hal-hal : Dalam hal ia berada di suatu kawasan yang potensi penularannya tinggi atau sangat tinggi berdasarkan ketetapan pihak yang berwenang maka ia boleh meninggalkan salat Jumat dan menggantikannya dengan shalat zuhur di tempat kediaman, serta meninggalkan jamaah shalat lima waktu/rawatib, Tarawih, dan Ied di masjid atau tempat umum lainnya (Sulaeman \& Supriadi, 2020; Zulkarnain, Nurdin, Gojali, \& Wahyu, 2020).

Dalam hal ia berada di suatu kawasan yang potensi penularannya rendah berdasarkan ketetapan pihak yang berwenang maka ia tetap wajib menjalankan kewajiban ibadah sebagaimana biasa dan wajib menjaga diri agar tidak terpapar virus Corona, seperti tidak kontak fisik langsung (bersalaman, berpelukan, cium tangan), membawa sajadah sendiri, dan sering membasuh tangan dengan sabun (Darmawan, Miharja, Waluyajati, \& Isnaeniah, 2020; Supriatna, 2020). Dalam kondisi penyebaran COVID-19 tidak terkendali di suatu kawasan yang mengancam jiwa, umat Islam tidak boleh menyelenggarakan shalat jumat di kawasan tersebut, sampai keadaan menjadi normal kembali dan wajib menggantikannya dengan shalat zuhur di tempat masing-masing. Demikian juga tidak boleh menyelenggarakan aktivitas ibadah yang melibatkan orang banyak dan diyakini dapat menjadi media penyebaran COVID-19, seperti jamaah shalat lima waktu/ rawatib, shalat Tarawih dan Ied di masjid atau tempat umum lainnya, serta menghadiri pengajian umum dan majelis taklim. Dalam kondisi penyebaran COVID-19 terkendali, umat Islam wajib menyelenggarakan shalat Jumat (Chaq, 2020; Syatar, Amiruddin, \& Rahman, 2020).

Pemerintah menjadikan fatwa ini sebagai pedoman dalam upaya penanggulangan COVID-19 terkait dengan masalah keagamaan dan umat Islam wajib mentaatinya. Pengurusan jenazah (tajhiz janazah) terpapar COVID-19, terutama dalam memandikan dan mengkafani harus dilakukan sesuai protokol medis dan dilakukan oleh pihak yang berwenang, dengan tetap memperhatikan ketentuan syariat (Subandi \& bin Anshor, 2020). Sedangkan untuk menshalatkan dan menguburkannya dilakukan sebagaimana biasa dengan tetap menjaga agar tidak terpapar COVID-19, d) Umat Islam agar semakin mendekatkan diri kepada Allah dengan memperbanyak ibadah, taubat, istighfar, dzikir, membaca Qunut Nazilah di setiap shalat fardhu, memperbanyak shalawat, memperbanyak sedekah, dan senantiasa berdoa kepada Allah SWT agar diberikan perlindungan dan keselamatan dari musibah dan marabahaya (doa daf'u al-bala'), 
khususnya dari wabah COVID-19, e) Tindakan yang menimbulkan kepanikan dan/atau menyebabkan kerugian publik, seperti memborong dan menimbun bahan kebutuhan pokok dan menimbun masker hukumnya haram (Dahlan, 2020; Mushodiq \& Imron, 2020).

Kemudian dilanjutkan dengan maklumat Mabes Polri bernomor Mak/2/III/2020 ini diteken langsung oleh Idham pada Kamis (19/3/2020) yaitu : a) Setiap kegiatan sosial, budaya, keagamaan, aliran kepercayaan dalam bentuk seminar, lokakarya, sarasehan dan sejenisnya ditiadakan. Perintah ini juga termasuk untuk kegiatan konser musik, pekan raya, festival, bazaar, pasar malam, pameran dan resepsi keluarga., Selanjutnya, diperintahkan untuk tidak mengadakan kegiatan olahraga, kesenian, jasa hiburan, unjuk rasa, pawai dan karnaval serta kegiatan lainnya yang menciptakan kerumunan massa. a). Idham juga memerintahkan seluruh pihak tetap tenang, tidak panik dan meningkatkan kewaspadaan di lingkungan masing-masing. Masyarakat juga diminta mengikuti informasi dan imbauan Pemerintah, $b$ ) Idham menuturkan kegiatan yang sifatnya mendesak dan tak dapat dihindari hendaknya diselenggarakan dengan tetap menjaga jarak dan mengikuti protokol pencegahan penyebaran virus Corona yang telah dibuat Pemerintah, c) Selanjutnya, Idham tak memperbolehkan adanya pembelian atau penimbuhan bahan pokok maupun kebutuhan masyarakat lainnya secara berlebihan. Idham juga meminta agar semua pihak tak terpengaruh dan menyebarkan berita-berita yang sumbernya tak jelas dan dapat menimbulkan keresahan di tengah masyarakat. Dia meminta masyarakat menghubungi polisi jika mendapat informasi yang tak jelas, d) "Apabila ditemukan perbuatan yang bertentangan dengan maklumat ini, maka setiap anggota Polri wajib melakukan tindakan kepolisian yang diperlukan sesuai ketentuan peraturan dan perundang-undangan yang berlaku," tegas Idham dalam maklumatnya. Hal ini senada dengan himbauan gubernur NTB yang menyatakan bahwa dilarang mengadakan pertemuan sosial, adat, budaya dan keagamaan dalam bentuk diskusi, seminar, pengajian , perayaan hari besar keagamaan, berbagai kegiatan festival adat budaya, musik dan olah raga. Tujuan dari Pengabdian Kepada Masyarakat di dasan Nyelak adalah untuk untuk mengurangi kebebasan bergaul anak usia sekolah dasar di tengah masa COVID-19 (Fathoni, 2019; Tuwu, 2020).

\section{Metode}

Kegiatan pengadian ini merupakan pengabdian yang dilakukan sebagai upaya untuk memberikan edukasi serta pemahaman kepada masyarakat khususnya kepada orangtua dan anak-anak Sekolah Dasar dalam pencegahan penularan Covid-19 melalui langkah edukasi social distancing. Kegiatan pengabdian ini dilaksanakan di Dusun Nyelak selama tiga hari. Kegiatan ini dilaksanakan melalui beberapa tahap yang dimulai dengan melakukan survey serta observasi lokasi pengabdian dengan melihat fenomena sejauh mana anak-anak memahami pencegahan covid-19. Setelah melalui survey lapangan masih ditemukan banyak anak-anak Sekolah Dasar yang sesusianya bermian dengan diluar rumah serta bemian dengan kerumunan tanpa mengindahkan prorotokol kesehatan hal ini dapat memberikan resiko tinggi penularan virus. Selanjutnya TIM konsep penyuluhan, menyiapkan jadwal kegiatan, serta mempersiapkan kebutuhan teknis kegiatan.Kegiatan ini dilakukan dengan memberikan penyuluhan kepada masyarakat khsusunya anak-anak dengan memanfaatkan suara pengeras yang tersedia di masjid di dusun Nyelak sehingga informasi dapat tersampaikan dan tidak menimbulkan kerumuaman.

\section{Hasil dan Pembahasan}

Pandemi covid-19 masih menjadi permasalahan di Indonesia saat ini. Begitu pula dengan di Nusa Tenggara Barat, Pemerintah telah melakukan upaya untuk mencegah penyebaran virus corona dengan cara menghimbau setiap individu untuk selalu melakukan social dan physical distancing guna mengurangi penyebaran Covid-19 (Lin, Zhang, Song, \& Omori, 2016). Seperti yang kita ketahui metode penularan virus corona kebanyakan berasal dari droplet atau tetesan yang timbul saat batuk, bersin, bahkan saat bernafas dan berbicara. Maka, Social dan Physical Distancing sangat penting pengaruhnya untuk mengurangi penyebaran virus corona (Flatten the curve). Seseorang tidak diperkenankan untuk berjabat tangan serta menjaga jarak setidaknya $2 \mathrm{~m}$ atau 3 kaki antara seseorang dengan orang lain saat berinteraksi. Bahkan saat di luar rumah terutama dengan orang yang sedang sakit memiliki sakit penyerta dan berisiko tinggi menderita Covid-19 (Mohler, et al., 2020; Su, et al., 2020).

Pengabdian ini dilaksanakan dengan memperhatikan protokol kesehatan yang dilakukan melalui audio dengan penyampaian yang sifatnya persuasif yang berupa ajakan kepada masyarakat dusun Nyelak untuk dapat mencegah penularan virus dengan memperhatikan protokol kesehatan salah satunya melakukan social distancing. Kegiatan penyuluhan ini dilakukan selama tiga hari, pada hari pertama menyampaikan fatwa MUI dalam hal ini atas nama penanggungjawab menteri agama RI dengan mendeskripsikannya dalam bahasa asli dusun Nyelak Kelurahan Kelayu Jorong. Hari ke dua 
menyampaian maklumat Kepala Kepolisian Republik Indonesia dalam penanganan covid-19. Hari ke tiga menyampaikan surat edaran pemerintah provinsi NTB tentang kewaspadaan segenap komponen masyarakat NTB dalam penanganan penyebaran covid-19. Pada pelakasanaan penyluhan masyarakat hanya bisa mendengan dari rumah masing-masing dengan memfokuskan perhatian mereka pada apa yang disampaikan demi menjaga jarak.

Setelah pelaksanaan pengabdian yang dilakukan selama tiga kali, kemudian dilakukan evaluasi serta survei lapangan, untuk meninjau serta mengevluasi sejauh mana kegiatan penyuluhan ini dapat dipahami dan dilaksanakan oleh masyarakat khusus anak-anak Sekolah Dasar. Hasil yang digapai dalam proses penyuluhan untuk social distancing anak usia sekolah dasar di tengah masa covid-19 di masyarakat dasan Nyelak kelurahan Kelayu Jorong mengalami beberapa perubahan. Adapun perubahan dimaksud yaitu : a) Golongan orang tua : mulai memahami pentingnya isolasi diri bersama anak-anak di rumah, menjaga anak adari berintraksi dengan siapapun di luar lingkungan rumah, mengawasi anak-anak mereka yang belajar, memberikan pembelajaran dan pemahaman pada anak-anak mereka, b) Golongan generasi muda : mulai membatasi diri dengan segala usaha untuk menekan berintraksi dengan teman sebaya, menjaga jarak, serta mau menjadi penggerak untuk diam di rumah saja, c) Anak-anak seusia Sekolah Dasar : bersungguh-sungguh dalam menjalankan tugasnya sebagai peserta didik yang harus belajar di rumah serta tidak bermain atau bergaul sosil dengan teman-temannya yang lain. Mulai belajar menghargai pemerintah dan orang tua yang dengan cara isolasi diri , mulai belajar dengan baik dimana anak-anak sering menanyakan ketidak fahamannya kepada orang tua masing-masing tentang pelajaran, sehingga dalam masing-masing rumah terdapat program belajar mengajar anatar anak dan orang tua.

\section{Simpulan}

Setelah melakukan Pengabdian Kepada Masyarakat dengan tujuan untuk mengurangi penularan covid-19 pada anak-anak Sekolah Dasar, anak-anak di dasan Nyelak Kelurahan Kelayu Jorong Alhamdulilah bisa mengurangi bermainnya dengan beritraksi sosial dengan teman sebaya mereka, masyarakat merasa bertanggungjawab terhadap kesehatan anak-anak mereka dengan cara memberikan penekanan dan pengawasan ketat pada keluarga masing-masing agar mengikuti himbauan pemerintah demi memutus mata rantai penularan Covid-19. Rencana tindak lanjut sudah dilakukan dengan mengagendakan penyuluhan dan pendisiplinan lagi terhadap anak-anak dan masyarkat jika terlihat anakanak dan warga ketahuan melanggar aturan dan himbauan pemerintah. Kegiatan ini diharapakan dapat menjadikan masyarakat memahami dan menyadari akan pentingnya mematuhi aturan pemerintah serta berusaha untuk memberikan edukasi kepada anak mengenai covid-19 agar terhindari dari penularannya.

\section{Referensi}

Buana, D. R. (2020). Analisis Perilaku Masyarakat Indonesia dalam Menghadapi Pandemi Virus Corona (Covid-19) dan Kiat Menjaga Kesejahteraan Jiwa. Salam: Jurnal Sosial dan Budaya Syar-i, 7(3), $217-$ 226.

Chan, J. F.-W., Zhang, A. J., Yuan, S., Poon, V. K.-M., Chan, C. C.-S., Lee, A. C.-Y., et al. (2020). Simulation of the clinical and pathological manifestations of Coronavirus Disease 2019 (COVID19) in golden Syrian hamster model: implications for disease pathogenesis and transmissibility. Clinical Infectious Diseases.

Chaq, M. D. u. (2020). Peran Fatwa Mui Dalam Penanggulangan Wabah Covid-19 Dan Dampaknya. Tafáqquh: Jurnal Penelitian Dan Kajian Keislaman, 8(1), 129-140.

Dahlan, M. (2020). Respon Jamaah Tabligh Terhadap Fatwa Majelis Ulama Indonesia Tentang Covid-19. Qiyas: Jurnal Hukum Islam Dan Peradilan, 5(1).

Darmawan, D., Miharja, D., Waluyajati, R. S. R., \& Isnaeniah, E. (2020). Sikap Keberagamaan Masyarakat Menghadapi Wabah COVID-19. Religious: Jurnal Studi Agama-Agama Dan Lintas Budaya, 4(2), 115-124.

Fathoni, A. (2019). Dampak Covic 19 Dan Kebijakan Psbb Pemerintah Terhadap Umkm Di Wiyung Surabaya. Dinar: Jurnal Prodi Ekonomi Syariah, 3(1), 30-69.

Hong, H., Wang, Y., Chung, H.-T., \& Chen, C.-J. (2020). Clinical characteristics of novel coronavirus disease 2019 (COVID-19) in newborns, infants and children. Pediatrics \& Neonatology, 61(2), 131132.

Lin, W.-Y., Zhang, X., Song, H., \& Omori, K. (2016). Health information seeking in the Web 2.0 age: Trust in social media, uncertainty reduction, and self-disclosure. Computers in Human Behavior, 56, 289-294. 
Mallineni, S. K., Innes, N. P., Raggio, D. P., Araujo, M. P., Robertson, M. D., \& Jayaraman, J. (2020). Coronavirus disease (COVID-19): Characteristics in children and considerations for dentists providing their care. International Journal of Paediatric Dentistry, 30(3), 245-250.

Mohler, G., Bertozzi, A. L., Carter, J., Short, M. B., Sledge, D., Tita, G. E., et al. (2020). Impact of social distancing during COVID-19 pandemic on crime in Los Angeles and Indianapolis. Journal of Criminal Justice, 101692.

Mushodiq, M. A., \& Imron, A. (2020). Peran Majelis Ulama Indonesia Dalam Mitigasi Pandemi Covid19 (Tinjauan Tindakan Sosial dan Dominasi Kekuasaan Max Weber). Salam: Jurnal Sosial dan Budaya Syar-i, 7(5), 455-472.

Rothan, H. A., \& Byrareddy, S. N. (2020). The epidemiology and pathogenesis of coronavirus disease (COVID-19) outbreak. Journal of autoimmunity, 102433.

Seah, I., \& Agrawal, R. (2020). Can the coronavirus disease 2019 (COVID-19) affect the eyes? A review of coronaviruses and ocular implications in humans and animals. Ocular immunology and inflammation, 28(3), 391-395.

Sood, S. (2020). Psychological effects of the Coronavirus disease-2019 pandemic. Research \& Humanities in Medical Education, 7, 23-26.

Stankovska, G., Memedi, I., \& Dimitrovski, D. (2020). Coronavirus COVID-19 disease, mental health and psychosocial support. Society Register, 4(2), 33-48.

Su, L., Ma, X., Yu, H., Zhang, Z., Bian, P., Han, Y., et al. (2020). The different clinical characteristics of corona virus disease cases between children and their families in China-the character of children with COVID-19. Emerging microbes \& infections, 9(1), 707-713.

Subandi, A., \& bin Anshor, S. (2020). Fatwa MUI Tentang Pengurusan Jenazah Muslim yang Terinfeksi Covid-19 Ditinjau dari Perspektif Mazhab Syafi'i. BUSTANUL FUQAHA: Jurnal Bidang Hukum Islam, 1(2), 235-250.

Sulaeman, S., \& Supriadi, S. (2020). Peningkatan Pengetahuan Masyarakat Desa Jelantik Dalam Menghadapi Pandemi Corona Virus Diseases-19 (Covid-19). Jurnal Pengabdian UNDIKMA, 1(1).

Supriatna, E. (2020). Wabah Corona Virus Disease Covid 19 Dalam Pandangan Islam. Jurnal Sosial \& Budaya, 7(6), 555-564.

Syatar, A. S. A., Amiruddin, M. M., \& Rahman, A. (2020). Darurat Moderasi Beragama Di Tengah Pandemi Corona Virus Desease 2019 (Covid-19). KURIOSITAS: Media Komunikasi Sosial dan Keagamaan, 13(1), 1-13.

Tezer, H., \& Demirdağ, T. B. (2020). Novel coronavirus disease (COVID-19) in children. Turkish Journal of Medical Sciences, 50(SI-1), 592-603.

Tuwu, D. (2020). Kebijakan Pemerintah dalam Penanganan Pandemi COVID-19. Journal Publicuho, 3(2), 267-278.

Zheng, W. (2020). Mental health and a novel coronavirus (2019-nCoV) in China. Journal of affective disorders, 269, 201.

Zulkarnain, F., Nurdin, A. A., Gojali, N., \& Wahyu, F. P. (2020). Kebijakan fatwa MUI meliburkan shalat jumat pada masa pandemi Covid 19. Kebijakan fatwa MUI meliburkan shalat jumat pada masa pandemi covid 19. 